University of Nebraska - Lincoln

DigitalCommons@University of Nebraska - Lincoln

USDA National Wildlife Research Center - Staff Publications
U.S. Department of Agriculture: Animal and Plant Health Inspection Service

6-1-2005

\title{
WEST NILE VIRUS SEROSURVEILLANCE IN IOWA WHITE-TAILED DEER (1 999-2003)
}

Julian Santatella

USDA/APHIS/WS National Wildlife Research Center, University of Caldas, Manizales. Columbia; University Hygienic Laboratory. University of lowa, Colorado Stare University, Coe College

Robert McLean

USDA/APHIS/WS National Wildlife Research Center, University of Caldas, Manizales, Columbia, University Hygienic Laboratory, University of lowa, Department of Biomedical Sciences, Colorado State University,

Coe College

Jeffrey S. Hall

USDA/APHIS/WS National Wildlife Research Center, University of Caldas, Manizales. Columbia; University Hygienic Laboratory. University of lowa, Colorado Stare University, Coe College

James S. Gill

USDA/APHIS/WS National Wildlife Research Center, University of Caldas, Manizales. Columbia; University Hygienic Laboratory. University of lowa, Colorado Stare University, Coe College

Richard A. Bowen

USDA/APHIS/WS National Wildlife Research Center, University of Caldas, Manizales. Columbia; University Hygienic Laboratory. University of lowa, Colorado Stare University, Coe College Follow this and additional works at: https://digitalcommons.unl.edu/icwdm_usdanwrc

Part of the Environmental Sciences Commons

See next page for additional authors

Santatella, Julian; McLean, Robert; Hall, Jeffrey S.; Gill, James S.; Bowen, Richard A.; Hadow, Harlo H.; and Clark, Larry, "WEST NILE VIRUS SEROSURVEILLANCE IN IOWA WHITE-TAILED DEER (1 999-2003)" (2005). USDA National Wildlife Research Center - Staff Publications. 50.

https://digitalcommons.unl.edu/icwdm_usdanwrc/50

This Article is brought to you for free and open access by the U.S. Department of Agriculture: Animal and Plant Health Inspection Service at DigitalCommons@University of Nebraska - Lincoln. It has been accepted for inclusion in USDA National Wildlife Research Center - Staff Publications by an authorized administrator of DigitalCommons@University of Nebraska - Lincoln. 


\section{Authors}

Julian Santatella, Robert McLean, Jeffrey S. Hall, James S. Gill, Richard A. Bowen, Harlo H. Hadow, and Larry Clark 


\title{
WEST NILE VIRUS SEROSURVEILLANCE IN IOWA WHITE-TAILED DEER (1999-2003)
}

\section{JULIAN SANTAELLA, ROBERT MCLEAN, JEFFREY S. HALL,* JAMES S. GILL, RICHARD A. BOWEN,} HARLO H. HADOW, AND LARRY CLARK

United State Department of Agriculture, Animal and Plant Health Inspection Service, Wildlife Services, National Wildlife Research Center. Fort Collins, Colorado, and University of Caldas, Manizales. Colombia; University Hygienic Laboratory, University of Iowa, Iowa City, Iowa; Department of Biomedical Sciences, Colorato State University, Fort Collins, Colorado; Biology Department, Coe College, Cedar Rapids, Iowa

\begin{abstract}
Sera from white-tailed deer (Odocoileus virginianus) were collected in Iowa during the winter months (1999-2003), 2 years before and after West Nile virus (WNV) was first reported in Iowa (2001), and were analyzed for antibodies to WNV. Samples from 1999 to 2001 were antibody negalive by blocking encyme-linked innmunusurbent assay (bELISA) and plaque reduction neutralization test ( PRNT $_{90}$ ). Prevalence derived from bELISA (2002, 12.7\%; $2003,11.2 \%)$ and WNV PRNT $90,(2002,7.9 \% ; 2003,8.5 \%)$ assays were similar. All samples were negative for antibodies against St. Louis encephalitis virus as determined by PRNT $_{\text {ri. }}$. Antibodies to flaviviruses were detected by indirect enzyme-linked immunosorbent assay (iELISA) prior to the first WNV cases reported in Iowa (1999-2001) with prevalence ranging from $2.2 \%$ to $3.2 \%$, suggesting the circulation of an additional undescribed flavivirus prior to the introduction of WNV into the area. Flavivirus prevalence as determined by iELISA increased in 2002 and 2003 (23.3\% and $31.9 \%$, respectively). The increase in prevalence exceeded estimates of WNV prevalence, suggesting that conditions favored general flavivirus transmission (including WNV) during the 2002-2003 epizootic. These data indicate that serologic analysis of deer sera collected from hunter harvests may prove useful for surveillance and evidence of local transmission of WNV and other pathogens and identify white-tailed deer as a species for further studies for host competency.
\end{abstract}

\section{INTRODUCTION}

West Nile virus (WNV) is a mosquito-borne, zoonotic Flavivirus (Flaviviridae) from Africa, the Middle East, Europe, and Asia llial elllerged as an invasive pallıogen in New York City during summer 1999. ${ }^{1,2}$ By winter 2004, human and other animal infections had been reported in Canada, all of the contiguous United States, parts of Mexico, and some islands of the Caribbean. ${ }^{3}$ The rapidity with which the pathogen disseminated across North America has been remarkable.

WNV is transmitted by many species of mosquitoes and uses a variety of birds as amplifying hosts. ${ }^{4.5}$ Although the vector and host competency of North American mosquitoes and birds are known to some extent, there are too few observations on the host competency of mammals to exclude them from being involved in the transmission cycle. ${ }^{6-8}$ Experimental infections of horses, dogs, and cats indicate that these species are either dead-end or poorly competent hosts." ${ }^{4}{ }^{10} \mathrm{At}$ least some rodents are competent hosts. ${ }^{11}$ However, little is known about the host competency of common mammalian wildlife in North America. ${ }^{12}$ Because of the considerable investment involved in experimental infection studies, the most economical approach to determine a species role in transmission is to survey wildlife populations for their risks of exposure to the virus. Once high-risk species are identified, their host competency can be tested experimentally. Identification of competent hosts and vectors is critical to understand the ecology of WNV and the factors important in driving disease cycles, and, by implication, forecasting temporal and spatial risks to human populations. ${ }^{13.14}$

Sera collected from white-tailed deer (Odocoileus virginiantus) during wildlife control operations and hunter-harvests

* Address correspondence to Jeffrey S. Hall, United States Department of Agriculture. Animal and Plant Health Inspection Service, Wildlife Services, National Wildlife Research Center, Fort Collins, CO 80521-2154.E-mail: Jeffery.S.Hall@aphis.usda.gov in lowa from 1999 to 2003 provided an opportunity to determine the deer's exposure to flaviviruses in general, and WNV and Saint Louis encephalitis virus (SLEV) specifically. Herein, we show that WNV is commonly transmitted to white-tailed deer and that this species should be further examined for its role in WNV transmission cycles. The utility of white-tailed deer as a surveillance indicator species also is discussed.

\section{MATERIALS AND METHODS}

Sample collection. Whole blood samples $(N=1,079)$ were collected from professional sharpshooter-killed deer, hunterkilled deer, and road-killed deer during the months of November-January. Most $(N=890)$ of the samples were collected in the years 1999-2001 and 2003 during the deer herd reduction program in Iowa City, Iowa. All shooting sites, except one, were in the northern part of the city; the other, single site $(N=24)$ was in the southern part of the city in 2000. 2001, and 2003. Most of the 189 samples in 2002 were collected by the Iowa Department of Natural Resources throughout the state from hunter-killed deer, but some were collected from fresh road-killed deer. The time from death to blood collection varied from 15 minutes to 4 hours. Freeflowing whole blood was obtained from skinned deer hanging from their hind legs when the thoracic cavity contents were removed. Dripping blood was collected in $7-\mathrm{mL}$ serum separator tubes. After clotting, the tubes were centrifuged and the serum removed and stored in cryovials at $-80^{\circ} \mathrm{C}$ until assayed.

Indirect enzyme-linked immunosorbent assay (iELISA). $A$ WNV iELISA was used to screen for flavivirus-specific immunoglobulin $\mathrm{G}$ (IgG) antibodies. ${ }^{15}$ This method may detect cross-reactive antibodies raised against other flaviviruses, thus it was viewed as a general screening method for flavivirus antibody detection. ${ }^{15}$

Positive and negative antigens were provided by New York State Department of Health's Wadsworth Center. ${ }^{16.17}$ Anti- 
gen was diluted (1:200) in coating buffer $\left(0.015 \mathrm{M} \mathrm{NaCO}_{3}\right.$, $0.035 \mathrm{M} \mathrm{NaHCO}_{3}, \mathrm{pH} \mathrm{9.6)}$ and applied $(50 \mu \mathrm{L} /$ well $)$ to the inner wells of a 96-well plate (Costar, Corning Incorporated, Corning, NY). Negative antigen was placed in every third column and positive antigen was placed in the remaining columns. Antigen binding to the wells was achieved by placing plates in a humidified chamber (plastic bag with a damp paper towel) and incubating $\left(4^{\circ} \mathrm{C}\right)$ them overnight. After incubation, antigen solutions were discarded and wells washed $(3 \times)$ with PBS-T (0.01 M phosphate buffer, $0.138 \mathrm{M} \mathrm{NaCl}, 0.0027$ $\mathrm{M} \mathrm{KCl}, \mathrm{pH} 7.4$ with $0.05 \%$ Tween 20 ). Next, blocking buffer (PBS-T with $2 \%$ casein) was added $(200 \mu \mathrm{L} /$ well $)$ and plates were incubated $\left(37^{\circ} \mathrm{C}, 1\right.$ hour $)$ in a humidified chamber. Blocking buffer was discarded, and test sera diluted in PBS-T with $0.5 \%$ bovine albumin (PBS-T-BA) (1:100 dilution) were added $(50 \mu \mathrm{L} /$ well) to duplicate wells. Five known negative control deer sera ( $\mathrm{PRNT}_{90}$ less than 1:10), one known positive control deer serum $\left(\mathrm{PRNT}_{9,0}\right.$ greater than 1:10), and one blank (buffer only) were included in each plate. Plates were incubated $\left(37^{\circ} \mathrm{C}, 1\right.$ hour $)$ in a humid chamber and after sera were discarded, washed $(3 \times)$ with PBS-T. After incubation, horseradish peroxidase conjugated rabbit anti-deer immunoglobulin IgG (Kirkegaard \& Perry Laboratories, Inc., Gaithersburg. MD), diluted 1:100 in PBS-T-BA, was added (50 $\mu \mathrm{L} /$ well) and incubated $\left(37^{\circ} \mathrm{C}, 1\right.$ hour). After incubation, the conjugate solution was discarded and the plates were washed $(3 x)$ with PBS-T and developed at room temperature (7 minutes) with tetramethylbenzidine (TMB)-peroxidase substrate (Kirkegaard \& Perry Laboratories, Inc.) $(50 \mu \mathrm{L} /$ well). The reaction was stopped by adding (50 $\mu \mathrm{L} /$ well) $\mathrm{H}_{2} \mathrm{PO}_{4}$ diluted 1:5.

Optical density (OD) was read at a wavelength of $450 \mathrm{~nm}$. Samples were considered positive if OD values were $\geq 3$ standard deviations above the mean $(\mathrm{OD}=0.055)$ of negative-control samples from 25 white-tailed deer (PRNT less than 1:10). Positive controls were obtained from 5 deer infected with WNV in Iowa (PRNT greater than 1:10) (National Veterinary Services Laboratories, Ames, IA), 3 deer infected with WNV in New York City (PRNT 1:10) (New York State Diagnostic Laboratory), and from 4 reindeer (> $90 \%$ inhibition by blocking ELISA) vaccinated (West Nile-Innovator vaccine, Fort Dodge Animal Health, Wyeth corporation) at the Denver Zoo, Denver, Colorado.

Epitope-blocking enzyme-linked immunosrobent assay (bELISA). A bELISA using the monoclonal antibody (MAb) $3.112 G$ was used to detect immunoglobulin $\mathrm{M}(\lg \mathrm{M})$ and $\mathrm{Igr}$ antibodies against WNV. ${ }^{18,19}$ This assay is specifically reactive to WNV, offers a high degree of sensitivity, and enables the assay to be taxon-independent in its ability to detect antibodies against the NS-1 epitope of WNV. ${ }^{18}$

WNV antigen was diluted (1:200) in coating buffer (see above) and applied ( $100 \mu \mathrm{L} /$ well) to the inner 60 wells of a 96-well plate. The plate was placed in a humidified chamber and incubated $\left(4^{\circ} \mathrm{C}\right)$ overnight. The next morning, the antigen solution was discarded, plates were washed $(4 \times)$ with PBS-T, and blocking buffer (PBS with 5\% skim milk) was added (200 $\mu \mathrm{L} /$ well) to each well. Plates then were incubated $\left(37^{\circ} \mathrm{C}, 40\right.$ minutes), after which blocking buffer was discarded and the plates were washed $(4 \times)$. Fifty microliters of test samples, diluted (1:10) in blocking buffer, were added to each well and incubated $\left(37^{\circ} \mathrm{C}, 2\right.$ hours). The test samples were then discarded, plates were washed $(4 \times)$, and MAb 3.1112G (Chemi- con Intern, Temecula, CA) diluted in blocking buffer (1: $2,000)$ was added $(50 \mu \mathrm{L} /$ well $)$ and incubated $\left(37^{\circ} \mathrm{C}, 1\right.$ hour $)$. After removal of MAb solution, plates were washed $(4 \times)$ and horseradish peroxidase-conjugated rabbit anti-mouse $\mathrm{IgG}$ (Zymed Laboratories, San Francisco, CA) (1:2,000 dilution) was added $(50 \mu \mathrm{L} /$ well $)$ and incubated $\left(37^{\circ} \mathrm{C}, 1\right.$ hour $)$. After removal of conjugate solution, plates were washed $(4 \times)$. ABTS substrate (2.2 azino-bis [3-ethylbenzthiazoline-6sulfonic acid]) and peroxidase solutions from the ABTS Microwell peroxidase substrate system (KPL, Gaithersburg. MD) were mixed 1:1, and were added ( $75 \mu \mathrm{L} /$ well). Optical density (OD) values were read at $415 \mathrm{~nm}$ in an automated plate reader.

Percent inhibition of MAb binding was calculated using the formula $^{18} 100-[(\mathrm{TS}-\mathrm{B}) /(\mathrm{CS}-\mathrm{B})] \times 100$, where TS is the OD of test serum, CS is the OD of negative control serum, and $\mathrm{B}$ is the background $\mathrm{OD}$. The percent inhibition was calculated once the control serum OD values exceeded 0.3 . An inhibition value of $\geq 30 \%$ was considered positive for the presence of anti-WNV antibodies. ${ }^{19}$

Plaque reduction neutralization test (PRNT). Differential diagnosis for antibody positive samples was confirmed by plaque reduction neutralization test (PRNT) against WNV and SLEV. ${ }^{19,20}$ Heat-inactivated samples $\left(56^{\circ} \mathrm{C}, 30\right.$ minutes $)$ were serially diluted twofold in BA-1 (Hanks M-199 salts. 50 $\mathrm{mM}$ Tris [pH 7.6], $1 \%$ bovine serum albumin, $0.35 \mathrm{~g}$ of sodium bicarbonate $/ \mathrm{L}, 100$ units of penicillin $/ \mathrm{mL}, 50 \mu \mathrm{g}$ of gentamicin $/ \mathrm{mL}, 2.5 \mu \mathrm{g}$ fungizone $/ \mathrm{mL}$ ), starting at a dilution of 1:5. Diluted serum $(100 \mu \mathrm{L})$ was mixed $(1: 1)$ with additional diluent containing approximately 200 PFU (plaque forming units) of virus and incubated $\left(4^{\circ} \mathrm{C}\right)$ overnight. Each serumvirus suspension $(100 \mu \mathrm{L})$ was inoculated onto confluent Vero cell monolayers in six-well plates and incubated $\left(37^{\circ} \mathrm{C}\right.$, 60 minutes). Overlay medium (MEM supplemented with $5 \%$ fetal bovine serum, $0.5 \%$ agarose and antibiotics as in BA-1) was added $(2 \mathrm{~mL} /$ well for WNV, and $3 \mathrm{~mL} /$ well for SLEV) and the plates were incubated $\left(37^{\circ} \mathrm{C}: 2\right.$ days for $\mathrm{WNV} ; 5$ days for SLEV), after which a second overlay containing $0.004 \%$ neutral red was added. Plaques were counted 24 to 48 hours after the second overlay, and titers expressed as the reciprocal of the highest dilution of the serum that yielded $\geq 90 \%$ reduction in the number of plaques (PRNT ${ }_{(\%)}$ ).

Statistical tests. Data were analyzed by $\chi^{2}$ and the binomial difference between proportions tests.

\section{RESULTS}

Prevalence of antibodies against flaviviruses as determined by indirect ELISA. White-tailed deer were exposed to flaviviruses throughout the observation period. Initially, prevalence of antibodies against flaviviruses was similar and low: $2.2 \%$. $2.9 \%$, and $3.2 \%$ for the years 1999.2000 , and 2001, respectively (Table $1 ; \chi^{2}=0.4, P=8.17$ ). The prevalence of antibodies against flaviviruses increased to $23.3 \%$ and $31.9 \%$ of the sampled population during 2002 and 2003, respectively (Figure 1A). This change in prevalence $(\Delta=+20.1 \%)$ represented a $628 \%$ increase in flavivirus antibody prevalence between the years 2001 and $2002(P<0.001)$. Deer populations continued to show an increase $(36.9 \%)$ in prevalence of antibodies against flaviviruses in the subsequent year (cf. 2002 versus $2003 ; \Delta=+8.6 \%, P=0.041)$. 
TABLE 1

Summary of flavivirus and WNV antibody prevalence as determined by screening iELISA, bELISA, and PRNT*

\begin{tabular}{llrcccc}
\hline Year & \multicolumn{1}{c}{ Age } & $\mathrm{N}$ & $\begin{array}{c}\text { iELISA } \\
\mathrm{n}+(\%)\end{array}$ & $\begin{array}{c}\text { bELISA } \\
\mathrm{n}+(\%)\end{array}$ & $\begin{array}{c}\text { WNV } \\
\mathrm{PRNT}(\%) \\
\mathrm{n}+(\%)\end{array}$ & $\begin{array}{c}\text { WNV } \\
\text { PRNT } \\
\mathrm{n}+(\%)\end{array}$ \\
\hline 1999 & Fawn & 117 & $4(3.4)$ & $0(0.0)$ & $0(0.0)$ & $0(0.0)$ \\
& Yearling & 50 & $1(2.0)$ & $0(0.0)$ & $0(0.0)$ & $0(0.0)$ \\
& Adult & 102 & $1(1.0)$ & $0(0.0)$ & $0(0.0)$ & $0(0.0)$ \\
& All & 269 & $6(2.2)$ & $0(0.0)$ & $0(0.0)$ & $0(0.0)$ \\
2000 & Fawn & 118 & $3(2.5)$ & $0(0.0)$ & $0(0.0)$ & $0(0.0)$ \\
& Yearling & 48 & $3(6.3)$ & $0(0.0)$ & $0(0.0)$ & $0(0.0)$ \\
& Adult & 141 & $3(2.1)$ & $0(0.0)$ & $0(0.0)$ & $0(0.0)$ \\
& All & 307 & $9(2.9)$ & $0(0.0)$ & $0(0.0)$ & $0(0.0)$ \\
2001 & Fawn & 45 & $0(0.0)$ & $0(0.0)$ & $0(0.0)$ & $0(0.0)$ \\
& Ycarling & 26 & $1(3.9)$ & $0(0.0)$ & $0(0.0)$ & $0(0.0)$ \\
& Adult & 55 & $3(5.5)$ & $0(0.0)$ & $0(0.0)$ & $0(0.0)$ \\
& All & 126 & $4(3.2)$ & $0(0.0)$ & $0(0.0)$ & $0(0.0)$ \\
2002 & Fawn & 24 & $5(20.8)$ & $3(12.5)$ & $3(12.5)$ & $4(16.7)$ \\
& Yearling & 33 & $4(12.1)$ & $2(6.1)$ & $1(3.0)$ & $1(3.0)$ \\
& Adult & 123 & $33(26.8)$ & $19(15.4)$ & $10(8.1)$ & $16(13.0)$ \\
& All $\dagger$ & 189 & $44(23.3)$ & $24(12.7)$ & $15(7.9)$ & $22(11.6)$ \\
2003 & Fawn & 62 & $10(16.1)$ & $3(4.8)$ & $3(4.8)$ & $5(8.1)$ \\
& Yearling & 53 & $20(37.7)$ & $6(11.3)$ & $4(7.5)$ & $7(13.2)$ \\
& Adult & 73 & $30(41.1)$ & $12(16.4)$ & $9(12.3)$ & $12(16.4)$ \\
& All & 188 & $60(31.9)$ & $21(11.2)$ & $16(8.5)$ & $24(12.8)$ \\
\hline
\end{tabular}

* SLE PRNT Y0 $_{40}$ and SLE PRNT assigned.

Prevalence of antibodies against West Nile virus as determined by blocking ELISA. There was no evidence of WNV transmission to white-tailed deer between 1999 and 2001 (Table 1; Figure 1B). Prevalence of antibodies against WNV was $12.7 \%$ in 2002 and $11.2 \%$ in 2003 . These rates were simi$\operatorname{lar}(P=0.661)$.

Prevalence of neutralizing antibodies to WNV and SLEV as determined by PRNT. None of the samples positive by iELISA $(N=19)$ prior to 2002 was positive by WNV PRNT $_{90}$ or SLEV PRNT ${ }_{90}$ (Table 1) Nor were any of the 2002 and 2003 iELISA positive samples positive by SLEV PRNT $_{90}$. The prevalence for neutralizing antibodies against WNV $\left(\mathrm{PRNT}_{90}\right)$ was $7.9 \%(N=188)$ and $8.5 \%(N=186)$ for 2002 and 2003, respectively. The values from the PRNT (Table 1) assay were were statistically identical to those estimated by bELISA. The difference in prevalence estimates by iELISA and bELISA indicate an unknown flavivirus was circulating in deer populations prior to 2002 , and that an increase in unknown flavivirus transmission occurred concurrently with WNV transmission in 2002 and 2003 (Figure 1C).

The sensitivity of the iELISA compared with $\mathrm{PRNT}_{90}$ was $98.18 \%$ and its specificity was $93.03 \%$. The sensitivity of the bELISA compared with PRNT $_{90}$ was $58,18 \%$ and its specificity $98.72 \%$.

There were no differences in antibody prevalence between males and females in $2002(Z=0.016 ; P=0.98)$ and $2003(Z$ $=1.585 ; P=0.113)$ by $\operatorname{PRNT}_{{ }_{0}}($ Table 1$)$. There also was no association between age and positive WNV serology in 2002 $\left(\chi^{2}=5.74 ; P=0.057\right)$ and $2003\left(\chi^{2}=3.26 ; P=0.196\right)$ by $\mathrm{PRNT}_{90}$ (Table 1). Prevalence for the naive age class, fawns, indicates that the annual exposure to WNV was around $5 \%$.

\section{DISCUSSION}

Through careful wildlife management practices over the past century, population sizes of white-tailed deer in the
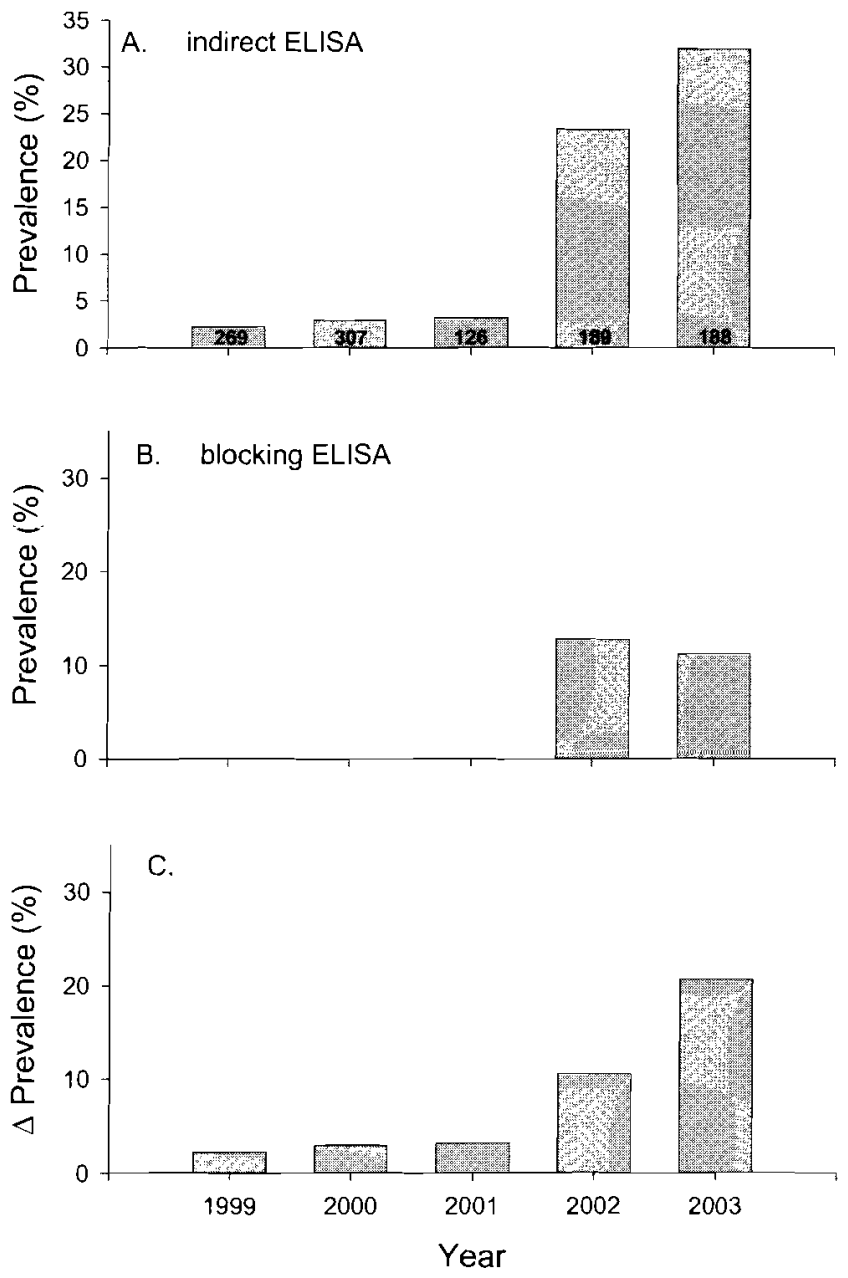

Figure 1. Prevalence of (A) antibodies against flaviviruses, as determined by indirect ELISA, (B) antibodies against Wes1 Nile virus, as determined by epitope blocking ELISA, and (C) the difference between prevalence as determined by iELISA and bELISA $(\Delta$ Prevalence) in Iowa white-tailed deer. Inset numbers indicate sample sizes. The difference in prevalence is taken as an indication of the transmission of some other non-WNV/SLE flavivirus during the course of the study.

United States have increased dramatically, Ieading to a bonanza of hunting opportunities for sportsmen, but causing problems of deer overpopulation in many areas. Because the numbers of deer harvested are large. the opportunity for costeffective serological surveys exists. ${ }^{21.22}$ Serologic surveys of deer may be particularly useful in locating foci of recent arbovirus activity because these animals seldom roam great distances, are relatively long-lived, and are easily accessible to biting or sucking arthropods. ${ }^{23,24}$ Hunter-killed deer are also useful in measuring temporal changes in annual antibody prevalences because these deer are only sampled once during a multiyear surveillance period.

The detaction of WNV-specific antibodies in white-tailed deer during 2002-2003 was consistent with other reports of WNV activity in the area. The prevalence as determined by WNV-specific bELISA and WNV-PRNT ${ }_{90}$ were concordant. The slightly higher prevalence found by $\mathrm{PRNT}_{90}$ over bELISA, while not statistically different, may be attributable to differing efficiencies of the two assays in detecting neutralizing versus non-neutralizing antibodies. ${ }^{18.19,25}$ Because the 
samples were obtained in the winter months. 3 to 4 months after the mosquito season was over, it is possible that a higher concentration of neutralizing antibodies was present in the sera. It may also be possible that because the bELISA uses a MAb targeted against an epitope in the NS1 protein, whereas antibody measured by PRNT is primarily directed against $\mathrm{E}$ protein epitopes, that the difference in prevalence may reflect a bias in response against these two proteins.

The antibody negative results found by bELISA and WNV PRNT $_{90}$ for 1999-2001 were expected because the first WNV case in Iowa (a dead crow) was reported in September 2001 in eastern Iowa, when the mosquito season was already ending. ${ }^{3}$ The prevalence of antibodies by these WNV-specific assays during 2002-2003 was consistent with other estimates of viral activity in the area (Table 2). More interesting was evidence of transmission of a non-WNV, non-SLEV flavivirus prior to the appearance of WNV in Iowa, and the dramatic increase in transmission of the(se) flavivirus(es) during 2002 and 2003. The increase in prevalence of the undescribed flavivirus in 2002 and 2003 suggests that environmental conditions favoring overall flavivirus transmission occurred coincidentally with the WNV epizootic. What these factors might have been remains to be determined. There is evidence for the circulation of other flaviviruses in the United States ${ }^{5.26}$ (e.g., the newly discovered tick-borne encephalitis-like virus provisionally named "deer tick virus," similar to Powassan virus ${ }^{27,28}$ ). Moreover, serological cross-reactions between flaviviruses and pestiviruses also have been demonstrated. ${ }^{29}$

There was no association found between sex or age and positive WNV serology in this study, consistent with previous results. ${ }^{30}$ Because the number of samples from fawns and yearlings from 2002 was less than 35 animals per age group, the prevalence found in this study might not be representative of what is happening in the field; further investigations with larger sample sizes for the different age groups is recommended to have a better understanding about the association between age and positive WNV serology. We found a higher prevalence, although statistically not significant, of antibodies to WNV in yearlings than in fawns and also a higher prevalence in adults than in yearlings in 2003. This could be caused by an increased opportunity for older animals to become infected as a result of living in an enzootic area for a longer period of time than younger animals, or by persistence of antibody over multiple years.

Although the antibody prevalences to WNV found in this study confirm WNV exposure in deer, there are no indications what effects WNV might have on the health of deer populations. However, transmission of WNV to white-tailed deer does occur, and it now remains to be determined through experimental infection studies their susceptibility, mortality, and reservoir potential to WNV. This information will lead to

TABLE 2

Number of West Nile virus positive cases reported in Iowa (CDC 2004)

\begin{tabular}{lrc}
\hline & \multicolumn{2}{c}{ Year } \\
\cline { 2 - 3 } & 2002 & $21 \times 13$ \\
\hline Human & 54 & 147 \\
Equine & 1159 & $96^{*}$ \\
Avian & 122 & $87^{*}$ \\
\hline
\end{tabular}

* The decline of reported equine and arian WNV cases in 2003 mav be due to vaccination of horses against WNV and restriction of dead bird testing by state health laboratorics. a better understanding of the role this species has in the ecological cycle of WNV.

In summary, we have provided serologic evidence for WNV infection in white-tailed deer from lowa. These results are consistent with human, veterinary, and bird cases reported in Iowa. Even though human case reports are good sources of information to detect activity of a virus in a region, sometimes these reports can be inaccurate because of difficulty in establishing a precise geographic area of exposure and because asymptomatic people do not get tested. Serologic surveillance studies in domestic animals are also useful but have problems because of the introduction of vaccines for WNV. In contrast, surveillance studies of white-tailed deer can provide an accurate, rapid, cost-effective, and easy way to monitor the activity of WNV in a region.

Received April 7, 2005. Accepted for publication July 11, 2005.

Acknowledgments: The authors thank the lowa Department of Natural Resources for collecting and providing sera specimens for serological analysis. The authors thank Dr. Mitchell Palmer at the National Animal Disease Center, Ames, Iowa, Dr. Felieia Knightly at the Denver Zoo, and Dr. Amy Glazer at the New York State Diagnostic Laboratory for providing control samples. The authors thank Kevin Bentler for kindly providing assistance in the laboratory. The authors thank Dr. Hector Jaime Aricapa at Caldas University for helpful comments and critical review of the study proposal. This study complies with the Principles of Animal Care, publication no. 86-23, revised 1985, of the National Institutes of Health and with current laws of the United States of America. This study was conducted under quality assurance protocol QA-1086 as part of the research project "Wildlife Diseases: Surveillance, Monitoring, Research, and Response" at the National Wildlife Research Center.

Financial support: Funding for this sludy was provided by the $\mathrm{Na}$ tional Wildlife Research Center. Fort Collins, Colorado.

Authors' addresses: Julian Santaella, Robert McLean, Jeffrey S. Hall, and Larry Clark, United States Department of Agriculture, Animal and Plant Health Inspection Service, Wildlife Services, National Wildlife Research Center, Fort Collins, CO 80521-2154. Telephone: (970) 266-6137. Fax: (970) 266-6138. James S. Gill, University Hygienic Laboratory, University of Iowa, Iowa City, IA. Richard A. Bowen. Colorado State University, Fort Collins, CO 80521. Harlo H. Hadow, Biology Department. Coe College, Cedar Rapids, IA 52402.

Reprint requests: Larry Clark, United States Department of Agriculture, Animal and Plant Health Inspection Service, Wildlife Services, National Wildlife Research Center, Fort Collins, CO 80521-2154, Telephone: (970) 266-6137. Fax: (970) 266-6138, E-mail: Larry Clark@aphis.usda.gov.

\section{REFERENCES}

1. Lanciotti RS, Roehrig JT, Deubel V. Smith J, Parker M, Steele K, Crise B, Volpe KE. Crabtree MB, Scherret JH, Hall RA, MacKenzie JS. Cropp CB. Panigrahy B. Ostlund E, Schmitt B. Malkinson M. Banet C. Weissman J. Komar N, Savage HM. Stone W, McNamara T, Gubler DJ, 1999. Origin of the West Nile virus responsible for an outbreak of encephalitis in the northeastern United States. Science 286: 2333-2337.

2. Nash D. Mostashari F. Fine A. Miller J. O'Leary D. Murray K. Huang A, Rosenberg A. Greenberg A, Sherman M, Wong S, Layton M, 1999. The outbreak of West Nile virus infection in the New York City area in 1999. N Engl J Med 334: 18071814.

3. CDC. 2004. West Nile Virus surveillance summary. 1999-2003. Atlanta. Georgia: U.S. Department of Health and Human Services. CDC. Available at: http://www.cdc.gov/ncidod/dvbid/ west nile/surv\& control.htm.

4. Hayes CG. 1989. West Nile fever. Monath TP. ed. The Arboviruses: Epidemiology and Ecology. Volume V. Boca Raton. FL: CRC Press. 59-88. 
5. Burke DS. Monath TP. 2001. Flaviviruses. Knipe DM. Howley PM. eds. Field's Virology. Fourth edition. Philadelphia: Lippincott Williams \& Wilkins. 1043-1126.

6. Komar N, Langevin S. Hinten S, Nemcth N, Edwards E. Hettler D. 2003. Exper intental inlection ol North Anter ican Birds wilh the New York 1999 strain of West Nile virus. Emerg Infect Dis 9: 311-322.

7. Garmendia AE. Van Kruiningen HJ. French RA. 200l. The West Nile Virus: its recent emergence in North America. Microb Infect 3: 223-229.

8. Malkinson M. Banet C, 2002. The role of birds in the ecology of West Nile virus in Europe and Africa. Curr Top Microbiol Immunol 267: 309-322.

9. Bunning ML, Bowen RA, Cropp CB, Sullivan KG, Davis BS, Komar N, Godsey MS, Baker D, Hettler DL, Holmes DA, Biggerstaff BJ, Mitchell CJ, 2002. Experimental infection of horses with West Nile virus. Emerg Infect Dis 8: 380-386.

10. Austgen LE, Bowen RA. Bunning ML, Davis BS, Mitchell CJ, Chang GJ, 2004. Expcrimental infection of cats and dogs with West Nile virus. Emerg Infect Dis 10:82-86.

11. Xiao S, Guzman H, Zhang H, Travassos da Rosa AP. Tesh RB, 2001. West Nile infection in the Golden Hamsicr (Mesocricerus auratus): a model for West Nile Encephalitis. Emerg Infect Dis 7: 714-721.

12. Root JJ. Hall JS. McLean RG, Marlenee NL. Beaty BJ. Ganowski J, Clark L, 2005. Serological evidence of exposure of wild mammals to flaviviruses in the central and castern United Statcs. Am J Trop Med Hyg 72: 622-630.

13. Hansen F, Jeltsch F. Tackmann K. Staubach C, Thulke H-H, 2004. Processes leading to a spatial aggregation of Echniococcus multilocularis in its natural intermediate host Microtus arvalis. Int J Parasitol 34: 37-44.

14. McCallum H, Barlow N, Hone J, 2001. How should pathogen transmission be modcled? Trends Ecol Evol 16: 295-300.

15. Ebel GD, Dupuis AP II, Nicholas D, Young D, Maffei J, And Kramer LD, 2002. Detection by enzyme-linked immunosorbent assay of antibodies to West Nile Virus in birds. Emerg Infec Dis 8: 979-982.

16. Frazier CL. Shope RE. 1979. Detcetion of antibodies to alphaviruses by enzyme-linked immunosorbent assay. J Clin Microbiol 10:583-585.

17. Ebel GD, Dupuis AP Il. Ngo KA. Nicholas DC, Kaulfman EB, Jones SA. 2001. Partial genetic characterization of West Nile virus strains. New York State. 2000. Emerg Infect Dis 7: 650651

18. Hall RA. Broom AK. Hartnett AC, Howard MJ. Mackenzie JS, 1995. Immunodominant epitopes on the NSI protein of MVE and Kunjin viruses serve as targets for a blocking ELISA to detect virus-specific antibodies in sentinel animal serum. $J$ Vir Meth 5I: 201-210.

19. Blitvich BJ. Marlenee NL, Hall RA. Calisher CH, Bowen RA. Roehrig JT, Komar N, Langevin SA. Beaty BJ, 2003. Epitopeblurking enzynte-linked inmunusurbent assays fờ déteclion of serum antibodies to West Nile Virus in multiple avian species. J Clin Microbiol 4I: 1041-1047.

20. Farajollahi A, Gates R, Crans W. Komar N, 2004. Serologic evidence of West Nile virus and St. Louis encephalitis virus infections in White-tailed deer (Odocoileus virginianus) from New Jerscy, 2001. Vector Borne Zoonotic Dis 4: 379-383.

21. Halls LK, 1984. White-Tailed Deer Ecology and Management. Harrisburg. PA: Stackpole Books, 870.

22. Gill J, McLean R, Shriner R, Johnson R, 1994. Serologic surveillance for the Lyme disease spirochete, Borrelia burgdorferi, in Minnesota by using white-tailed deer as sentinel animals. $J$ Clin Microbiol 32: 444-451.

23. McLean R, Kirk L. Shriner R, Cook P. Myers E. Gill J. Campos E. 1996. The role of deer as a possible reservoir host of Potosi virus, a newly reconnized arbovirus in llate Uniled Slates. $J$ Wild Dis 32: 444-452.

24. Emmons RW. 1968. Serologic survey of a deer herd in California for arbovirus infections. Bull Wildl Dis Assoc 3: 78-80.

25. Casals J, 1973. Arbovirus infections. Paul JR, White C. eds. Serological Epidemiology. New York: Academic Press, 99-177.

26. Whitney E, Roz AP, Rayner GA. Deibel R, 1969. Serologic survey for Arbovirus activity in deer sera from nine counties in New York State. Bull Wildl Dis Assoc 5: 392-397.

27. Telford 11I Sr, Armstrong PM, Katavolos P, Foppa 1, OlmedaGarcia AS. Wilson ML. Spielman A, 1997. A new tick-borne encephalitis-like virus infecting New England deer ticks, $I x$ odes dammini. Emerg Infect Dis 3: 165-170.

28. Ebel GD, Foppa I. Spielman A, Telford SR, 1999. A focus of deer tick virus transmission in the North central United States. Emerg Infect Dis 5: 570-574.

29. Heinz FX, Collet MS, Purcell RH, Gould EA. Howard CR Houghton M, Moormann RJM. Rice CM, Theil HJ. 2000 Family Flaviviridae. Van Regenmortel MH. Fauquet CM, Bishop CM. Carsten DHL, Estes E, Lemon MK, Maniloff S. Mayo J, McGeoch MA, Pringle D, Wickner RB, eds. Virus Taxonomy. Seventh Report of the International Committe' for the Taxonomy of Viruses. San Diego: Academic Press, 859878.

30. Ludwig GV. Calle PP, Mangiafico JA, Raphael BL, Danner DK, Hile JA, Clippinger TL, Smith JF, Cook RA, McNamara T, 2002. An outbreak of West Nile Virus in a New York city captive wildlife population. Am J Trop Med Hyg 67: 6775. 
